\title{
National Identity for Breakfast: Food Consumption and the Everyday Construction of National Narratives in Estonia
}

\author{
Abel Polese $^{1 \star}$ (D), Oleksandra Seliverstova ${ }^{2}$, Tanel Kerikmae ${ }^{3}$ and Ammon Cheskin ${ }^{4}$ \\ ${ }^{1}$ Dublin City University, Dublin, Ireland; Aleksanteri Institute, University of Helsinki, Helsinki, Finland; Tallinna \\ Tehnikaulikool, Tallinn, Estonia; ${ }^{2}$ Tallinn University, Tallinn, Estonia; ${ }^{3}$ Tallinna Tehnikaulikool, Tallinn, Estonia; and \\ ${ }^{4}$ University of Glasgow, Glasgow, United Kingdom of Great Britain and Northern Ireland \\ ${ }^{\star}$ Corresponding author. Email: abel.polese@dcu.ie
}

\begin{abstract}
Political debates on the Baltics, and in particular Estonia, have often pointed to "nationalisting" and exclusive narratives constructed at the institutional level. Accordingly, emphasis has been put on the lack of opportunities for Russians to integrate into an Estonian context. While acknowledging the shortfalls of the Estonian political project, this article contrasts these views in two ways. By emphasizing people's agency and their capacity to question, contrast, or even reject the identity markers proposed by Estonian official narratives, we maintain that the integration of Russians might be more advanced than insofar claimed by other studies. We then look at the way identities are lived in an everyday context by inhabitants of Estonia to counterpose national narratives proposed by the state and its political institutions, with the way people live and whether they accept these narratives. By doing this, we explore the role of the everyday in the reconstruction of national identity narratives, in which citizens actively participate in their individual capacity. We suggest that, from a James Scott "infrapolitics" perspective, these micro-actions have a fundamental role in the reshaping of a national identity and its acceptance among citizens.
\end{abstract}

Keywords: consumption; consumer citizenship; Estonia; identity

\section{Introduction: Everyday Identities and Methodological Dilemmas}

With 1.3 million Russian speakers and 1 million ethnic Russians, the Baltics remain under close scrutiny for their attitude toward Russian minorities. We refer, in particular, to the progressive phasing out of Russian medium language schools and the limitations in access to citizenship and labor rights. ${ }^{1}$ Accordingly, academic representations of the situation in the Baltics largely have been framed around inter-ethnic and political questions (Agarin 2010; Cheskin 2013; Ehala 2009) and have been grappling with questions of how discriminated Russians are (Laitin 1998; Galbreath 2005) with regards to issues ranging from obstacles to citizenship and voting rights (Hughes and Kwok 2006; Woolfson 2010) to marginalization on the job market (Aasland, 2001; Leping and Toomet 2008; Siiner 2006; Vetik and Helemäe 2011). These concerns have found fertile ground on what Rogers Brubaker's "nationalising the state" framework (1995).

In contrast with these views, our article suggests that state-centered nation-building, that is political measures proposed by the country's political elites to convince citizens that they all belong to a national community, cannot alone be considered "accountable" for national identity formation in Estonia. Whilst sharing some of the concerns raised by scholars and international organizations on some aggressive expressions of nationalism in the Baltics, we acknowledge that informal and

(C) Association for the Study of Nationalities 2020. This is an Open Access article, distributed under the terms of the Creative Commons Attribution licence (http://creativecommons.org/licenses/by/4.0/), which permits unrestricted re-use, distribution, and reproduction in any medium, provided the original work is properly cited. 
everyday actors and other dynamics contributing to identity construction in the Baltics have been largely overlooked. To address this deficiency, we propose looking at the way non-institutional actors and ordinary citizens in Estonia act to contrast, challenge, reproduce, and renegotiate national identity - or at least the idea of national identity that is put through formal channels by the state and state-managed actors. Borrowing from Thomas Eriksen's distinction between formal and informal nationalism (1993), we challenge the overemphasis on formal nationalism as proposed by the state through official narratives by proposing a narrative on the ways national identity is constructed by market actors and common people who engage in a day-by-day reinterpretation of state-led instructions.

To do so, we look at the gap between how identity policies are conceived by state actors and how they are lived by the people by looking at the way identity is constructed, negotiated, and reproduced in an everyday context. Our suggested approach is to look at the way common people live, accept (or reject) identity policies, and reproduce (or renegotiate) identity markers. This is also where our argument seeks to dialogue with the other articles in this special issue, and with its general approach. We contend that "the everyday" as an approach is an opportunity to explore the way national identity is lived, and reproduced day by day, by ordinary citizens. State-constructed narratives are not automatically accepted by the population they target but might generate tensions, discrepancies, or even rejection. This would not be an isolated case. Elsewhere in the former Soviet Union, and beyond, people look for compromises between what a society demands of them to integrate and what they can offer given a limited amount of resources, time, or simply unwillingness to fully commit to the whole nation-building project (Isaacs and Polese 2016; Polese et al. 2018; Richardson 2008; Rodgers 2007).

From the moment we wake up to the time we go to bed we perform a number of actions, some of which have little to do with politics. But others are indeed informed, directly or indirectly, by our ideology. In line with what Scott suggested, it is possible to suggest that their aggregate at a community or country level can eventually influence how policies are received and, eventually, policymaking. In this respect, our choice to look at the way people live and perform consumption, and in particular food consumption, is based on several criteria.

First, food is related to the everyday. Food consumption is an action performed, day-by-day, by all inhabitants of a given country. Once it is possible to associate certain foods, or patterns of consumption, with official narratives on national identity, a study of the trends of food consumption may shed light on the way consumer patterns within a society can be dictated, not only by economic rationales but with the perception of the symbolic values associated with this or that food. Second, food and consumption in general have been long acknowledged as a proxy for identity issues (Hervouet 2003; Zanca 2003). From the concept of conspicuous consumption (Veblen 1899) to the most recent studies on post-socialist consumption, food has been considered from a variety of angles, including as a lens to study identity-related issues (Bulakh 2017; Caldwell 2004, 2004b; Pechurina 2017). Third, food indeed has a political significance, especially since there is a political discourse giving certain meanings to certain foods and the choice to consume a given product. This is tendency that we have identified for the Baltics, and especially Estonia, and thus allows a given food to have a symbolic political meaning (Polese and Seliverstova 2018). Fourth, food-related practices can be regarded as a shortcut, or a faster way, to perform identity. Indeed, food consumption may be regarded as a relatively inexpensive, literally and especially metaphorically speaking, way to purchase markers of national identity. Learning the national language, or accepting the official narrative on the history of the country, may be time-consuming, expensive in terms of resources, and emotionally difficult. In contrast, consuming national food can be regarded as a shortcut, an easier attempt at a compromise with the national identity. ${ }^{2}$

In our case, use of such an empirical focus to challenge the top-down version of identity construction results in the choice to take into account the everyday as a methodological approach. Seeking continuity from a tradition of the study of the everyday (De Certeau 1998; Lefebvre 1974) 
authors have attempted to look beyond officially-produced narratives of loyalty and belonging (Nimmerfeldt, 2011; Pawłusz, 2017; Pawłusz and Polese 2017; Seliverstova 2017; Wulf, 2016). Whilst accepting that elites have the latitude to articulate various identity markers and construct an official narrative on national identity and participation, an emphasis has been put on the capacity by common people to renegotiate and even reject these narratives (Perchoc 2013; Polese 2010; Richardson 2008; Rodgers 2007; Ehala 2009). We take inspiration, here, from a number of studies on other world regions (Edensor 2002; Fox 2017; Skey 2015). This is where identity has been conceived, or better re-defined, as constructed on a daily basis by societies that are, in turn, nothing but the aggregate of daily individual aspirations.

We are aware that the study of everyday nationalism, and identity construction, represents a further challenge for the researcher. From a statist or institutional perspective, the loci of nationalism are relatively well defined (Isaacs and Polese 2016) and clearly expressed through laws, political declarations, institutions, and symbolic representations of a nation (be these museums, national holidays, or national symbols). By contrast, an everyday approach requires extrapolation of information to recreate, understand, and explain the way people, or a target group, live certain instructions, markers, and decisions in their daily life, and how their daily life is affected by these measures and by their perception of, and compliance with, these measures.

To inquire about cultural references, and the way people lived them, our usual approach has been to initially try to understand the original intentions of the legislator and its expected impact on the people. This includes an exploration of the unintended consequences of these dynamics. In other words, when conceiving measures aimed at increasing social cohesion, what were the intentions of the legislator and what were the measures that resulted? Likewise, it would be naive to expect that a policy measure would be adopted and accepted by the people in exactly the way the legislator intended. The approach proposed by Herzfeld in his Cultural Intimacy (2005), suggests comparing both top and bottom aspects of a society, to become "intimate" with cultural references and the way they affect people's perceptions and attitudes. Through this multi-layered exploration, we can take into account both the intended and unintended consequences of national identity construction as documented by the definition of nation-building named "spontaneous" (Polese and Horak 2015).

We are aware that this integrated approach requires the capacity of gathering data and analyzing them at several levels of a state and its society. Accordingly, the choice to involve a relatively large team in the preparation of this study is due to the capacity of each of its members to contribute data or interpretation from different angles. The core material for this article was collected in the frame of a doctoral project that was defended in 2017 (Seliverstova 2017) and was informed by 25 informal semi-structured interviews, conducted in Tallinn in 2014-2015 with representatives of two language groups-Estonian and Russian speakers. ${ }^{3}$ The snowball sampling method was used for finding potential respondents, defined as urban citizens representing either the educated middle class or lower-middle-class and born between 1950-1990. To complement the data derived from interviews, the research was augmented by intensive observation of consumption sites, such as markets and supermarkets in Tallinn. A second set of data was collected in the frame of a study on food preparation and consumption among Estonian residents. In that case, ethnography and informal interviews were used to gather information from common people and restaurant owners and managers. Interviews were spread throughout a longer period (2013-2017) and their initial focus was not ethnic or identity, but rather attitude toward society. As sometimes happens, however, a side effect of the project was to tease out of informants their relationship with the state and "Estonian-ness." Once the first empirics were collected and interpretation started, our discussions pointed to the fact that what we were hearing from informants was not necessarily what official state narratives were intended to produce across Estonian residents.

Once we gathered sufficient empirical data, we understood that it was necessary to deepen our understanding of the socio-political context, and we started an analysis of state-prepared material and e-material. We looked at the way tourism narratives were allegedly politicized to give a specific interpretation of what is Estonia (Pawlusz and Polese 2017), at the nation branding strategies of the 
Estonian state with particular attention to the e-residency program, and attempts to attract investors and funds (Polese et al. 2020). Given the focus of the article, we took particular care in looking at food narratives through a three-layer approach. First, we looked at the way Estonian political elites describe Estonian food and create a narrative around it through the official Estonian food website but also tourism brochures. Second, we looked at the way "national," "domestic," "patriotic," and "traditional" food consumption was used as a marketing strategy and how receptive Estonians were to such discourses. The invention of new dishes is not centralized in Estonia and, by force of the market, it is impossible to predict which kinds of food will become more popular. But we were able to identify some tendencies by commercial actors, such as the adoption of foreign products and foods and their "Estonianization" as well as the branding strategies used by some restaurants and eateries. We noted these tendencies, then asked our informants what they thought of them and to what extent they could identify with them. The result is a qualitative but systematic account of the ways food is lived and used as a cultural reference by Estonian inhabitants, that we contrast with the idea that national identity, in the country and beyond, is mostly elite-driven. In contrast, we emphasize the role that common people and the everyday have in the definition and negotiation of a national identity in Estonia as well as elsewhere.

Although this article is based on a sole case study, we contend that our theoretical claim can easily be extended well beyond the Baltic region. We regard national identity as the result of negotiation between at least two sets of forces. On the one side, we have the state and institutionalized actors that adopt measures and (try to) suggest a given range of identity markers to a target group, usually the citizens or the society. On the other side, we have that very target group: ordinary people and associations of people, both in the business and cultural sphere. The next two sections explore current debates on consumer choices and identity construction in the Baltics and beyond. They are followed by two case studies. The first looks at the way national recipes and national cuisine have been interpreted, often in a political and politicized way, and how this is challenged by the way people perceive such recipes. It also looks for inconsistencies in the narrative, identified through an analysis of marketing strategies. The second case study uses a similar framework, with an analysis of national foods through governmental sources.

\section{Consumer Choices and the Construction of Identities}

The importance of consumption goes well beyond its initial economic significance. Indeed, consumption has been given increased prominence in the analysis of identity formation in the post-modern era (Bauman 1998; Belk 1988; Douglas 2002; Dunn 2008; Elliott 2004; Miller 1995). Initially studied mostly through an anthropological lens (Douglas 2002; Douglas and Isherwood 1996; Miller 1995, 2001), the idea of construction of identity through consumption has recently been taken up by other disciplines. Within nationalism studies, multiple scholars have engaged with the mutual dependence between national identity and consumption (Fox and Miller-Idriss 2008; Skey 2011). Largely building on Billig's influential work on "banal nationalism," these scholars have developed the concept of consumer citizenship (Foster 2002; Foster and Özcan 2005; Trentmann 2007), giving an important, if not leading role, to consumption as a means to understand the sociopolitical engagement of ordinary people in nation-building processes.

In a framework inspired by Gudeman (2008), consumption may be regarded as composed of two different realms: the economic and the symbolic. Why do we sometimes pay more for what we could buy at a lower price from another brand? Or choose to consume a given product? Some of these answers can be found in economic motivations, but economics-based rational choice frameworks alone offer a limited framework to understand the symbolics of consumption and the behaviors that are embedded in symbolic or ideological choices-such as boycott campaigns (Bulakh 2017; Polese et al 2017b; Seliverstova 2017). Our understanding of consumption is of a site where symbolic meanings, markers of national belonging, and citizenship are being produced and renegotiated. By being exposed to the same set of products, commercial media, and everyday discourses 
accompanying consumption practices, people participate in an imaginary community of citizenconsumers (Foster 2002). By force of this, the act of consuming or not consuming a given product is, ultimately, an individual if not necessarily ideological choice, whose marginal importance might not be appreciated by quantitative analyses. Since the publication of "Weapons of the Weak," Scott (1985) has been suggesting that individual everyday acts of resistance, if performed by a growing number of people, can grow in importance, ending up affecting, often significantly, local, regional, or national policies. When a substantial number of individuals engage in the same action, even if they are unaware of other people doing the same thing, they create the basis for a social movement which can remain in the shadows, informally affecting social, economic, or political development of a country.

This reasoning has informed a number of works on identity in the post-socialist region and helped to shed light on the importance of phenomena that had fallen off of the radar of scholars for some time. From mega-events to collective singing, from informal reproduction of traditions to clumsy political decisions, identity is constructed by a variety of everyday synergies between micro and macro actors (Bulakh 2017; Datunashvili 2017; Isaacs 2015; Menga 2015, 2016; Strzemanska 2017). These actors are not necessarily political, just as the actions they perform need not have political significance, at least initially. But they have informed a framework that has been defined as "spontaneous" or "informal" nation-building (Isaacs and Polese 2015; Pawlusz 2017; Polese and Horak 2015; Polese et al. 2018). Emphasis has been put on processes and approaches that have the potential to affect national identity before they become widely accepted or acknowledged. When a political elite proposes a national marker, there is no guarantee that it will be widely accepted. Have all patriotic songs (or symbols) proposed by political elites become national hits, always and everywhere? A given marker might be replaced by various others that are created, consciously or not, by other actors. Therefore, besides state actors, the public, the business sector, cultural elites, or even groups and individuals antagonistic toward the state might contribute to the creation of markers that outlive state-created ones.

It becomes important, therefore, to explore both official narratives and unofficial ones, to expand the realm of the political to encompass a wider range of phenomena and actors, to examine the intentions of the political elites (Mylonas 2013), and see to what extent they compare to actual outcomes (Agarin 2010; Morris 2012; Perchoc 2012; Polese 2010, 2011). This varied approach follows those that have been suggested by several major scholars, from Herzfeld's cultural intimacy (2005) to Eriksen's formal and informal nationalism (1993). After all, state and the society complement and interact with one another in a never-ending exchange of ideas and symbols (Migdal 2001), as we will show in the next sections.

\section{Invisible Identities}

Academic representations of the "Russian question" in the Baltics have tended to emphasize real and perceived discrepancies between ethnic communities (Agarin 2010; Cheskin 2013; Ehala 2009; Kerikmae 2001; Korts 2009; Vetik and Helemäe 2011), with Russians regarded as suffering from a "sense of abandonment" (Laitin 1998; Lauristin and Heidmets 2002; Kolstø 2016; Galbreath 2005), thus grappling with question of how discriminated Russians are. This has been widely covered with regards to their limited political representation and obstacles to citizenship and voting rights (Hughes and Kwok 2006; Woolfson 2010), restricted access to the job market (Aasland, 2002; Leping and Toomet 2008), and lower incomes (Aasland 2002; Jacobson, 2006; Laitin 1998; Siiner 2006; Vetik and Helemäe 2011). In contrast to this scholarship, an emerging body of work has attempted a critical revisiting of these issues. Drawing from the concept of cultural intimacy by Herzfeld (2005), one can consider traditions and attitudes as resulting from a synergy between top (the state and its institutions) and bottom (citizens and non-state actors) forces in a given society. Second, by doing this, one could endorse the multi-faceted construction of the political suggested by Navarro-Yashin (2020), who stretches the boundaries of political actions to non-political and nonpoliticized actors, eventually reaffirming the inter-relatedness and entwisted relationship between a 
state and a society (Giddens 1984; Migdal 2001). The above arguments can be used to expand our imaginary circle of actors that can make significant choices in a given society or country. We assume that, however insignificant individual choices might look, they contribute to the aggregate of preferences expressed within a country. These preferences determine, to a certain extent at least, the reaction from a number of actors (not only the state but also market forces, trying to match societal demands with adequate supplies built on consumer's preferences). Second, inasmuch as identity construction can be considered a top-bottom process, there are a significant number of forces that still influence identity construction and come from a variety of actors, situations, and contexts (Fabrykant 2018; Gaufman 2018; Iglesias 2017; Knott 2015).

Laboring under the assumption that current tools are not sufficient to comprehensively explore the complexity of identity construction, in the post-Soviet world and elsewhere, a growing number of studies have been looking at non-traditional loci of identity construction (Isaacs and Polese 2016; Ó Beacháin 2016; Ó Beacháin and Kevlihan 2013; Pawlusz and Seliverstova 2016; Polese et al. 2017, 2018). With this article, we align with the need for a more nuanced study of identity dynamics that counterpose top-down and bottom-up or bottom-originated processes, to find a mid-way that acknowledges the importance of agency and the everyday level and its importance in the reproduction of identity narratives. This may go as far as to oppose state instructions and push the political elites into decisions they would not have conceived of without this pressure (see Polese et al. 2017b). Through a mechanism that Scott has come to call infrapolitics, he argues that "the accumulation of thousands or even millions of such petty acts can have a massive effect for warfare, land rights, taxes and property relations" (Scott 2014, xx). This approach emphasizes the possibility to challenge the monolicity of state structures and decisions (Kasza 2002), and to warn that political processes do not automatically follow political will all the way down, but are renegotiated at every stage and can end with a result much different from the initial intention.

The everyday, like other qualitative approaches, can certainly be regarded with skepticism in that it risks providing a limited understanding of the spread of a phenomenon. As a counterargument, a recent book edited by one of the authors (Morris and Polese 2014) featured a methodological experiment. Editors maintained that even a one-person case study could be used as a proxy to understand the depths of a given tendency, as long as the informant, their context, and society have been accurately chosen and analyzed. After all, as Barth said, "By focusing the comparison on the way in which social interaction is constituted and channeled in different systems rather than on the institutional features of different societies, it is possible to ignore the question of scale in membership when constructing the dimensions for comparison," (Barth 1981, 133).

It is not incidental that phenomena originating at the bottom of a society are, and may remain, invisible to the world, or even scholar communities, unless they "make it to the headlines." How many people noticed the anti-austerity movement in Spain until it officially gathered millions of followers and formed a national movement? Or how many people are aware that Daesh (also known as ISIS) is not a product of 2014 but its cells had been active for a decade when it became world famous? Closer to our region, this attitude can help explain why civil society was considered weak, absent, or insufficient (Howard 2003) in the post-socialist world, but was all of sudden one of the main actors in successful, and less successful, color revolutions (Ó Beacháin and Polese 2010).

Informal, non-political, or politicized, resistance and social movements might ultimately be regarded as two sides of the same coin, or two phases in the lifespan of a phenomenon (Polese and Kevlihan 2015). They are two possible developments of the same initial situation in which ethos and pathos of a state and its citizens (initially a low number, then possibly a growing one) diverge. This is not a novel claim. Already in 1968, Hobsbawm and Rude suggested that social phenomena tend to be ignored until they make headlines. For the case of Estonia, this brings to our attention the salience of the political realm, where those who contribute to the construction of political discourse are acknowledged, their voices heard and formally integrated within official narratives. However, we cannot either ignore the existence of a semi-official or informal dimensions where participation in political processes happens through non-traditional means and non-traditional channels. 
National identity formation and redefinition of identity markers can follow the same pattern. Gellner suggested that there are millions of potential nations (2008) but only a few of them will make it to recognition, statehood, and, ultimately, survival. The role of political elites and intellectuals is certainly pivotal but sometimes not sufficient for a nation to emerge. Ultimately, there are a number of forces operating "in the shadows" or sometimes contributing to the construction of national identity by chance, by mistake, or by unintended consequences (Horak and Polese 2016; Polese 2009). Political elites can suggest an identity, can think of ways to promote a given identity, (Chanet 1996) but national construction eventually happens in the every day. Accordingly, identity needs to be accepted, day-by-day, by a significant amount of people belonging to a given population, and this is a process much longer than usually considered (Connor 1990; Weber 1976).

\section{Estonian Recipes: Genuine, Natural, and, Above All, National(istic)}

Estonia's official position with regard to the Soviet period has been made clear through the creation of lieux de memoire across the country, actively promoting the notion of a rupture with the Soviet past (Eglitis 2002; Smith et al. 1996). The Soviet period is classified as a bleak one, imposing itself upon the "natural" history of an otherwise splendid and flourishing nation. Attempts to "forget the Soviet past," or to claim it is over, are visible and widespread. ${ }^{4}$ Estonia has gone as far as to go through a sort of food revolution. To this end, the website "Estonian food" (http://estonianfood.eu/ en; https://www.eestitoit.ee/en), launched by the Estonian Ministry of Rural Affairs, can be regarded as a way to assert "Estonian-ness" through the appropriation of recipes and foods that are declared "proper to Estonia" (or the Estonians). Whilst not denying the multi-cultural history of the country, the website puts an emphasis on the capacity of its people to "smartly" absorb cultural influences and give them some sort of Estonian twist, while remaining faithful to some fair degree of "Estonian-ness." The website starts from the question "What is Estonian food?" but, with the word "Estonia" present in six out of nine index entries, the emphasis on the country, and Estonian-ness, stands out clearly from the very first screen. Further sections of the website make you almost forget that Estonia has been under foreign influence and post-Soviet domination for a significant period. Food is presented here as conceived for every season and with fans worldwide. While spending time explaining the importance of mustard to Estonians, the website compares the local variety with the one in "Nordic countries" where it is milder and sweet, thus somehow placing the country in the north, rather than east of Europe. In many other cases, comparison with Northern countries is used to draw attention away from eastern or even Baltic references, let alone Soviet ones (Jordan, 2014b; Polese 2017). This can be regarded as a careful attempt to identify a relationship between a people, its land, and its natural produces. Here one can learn that:

Estonians have always loved to grow different kinds of roots, tubers, vegetables, fruit and berries. As most of the population lives in urban areas with little space for garden plots, then options such as growing fruit trees in the backyards of apartment block buildings, little urban greenhouses and growing simpler vegetables on windowsills are gaining popularity. 5 (https:// www.eestitoit.ee/en/content/vegetables)

If the above narrative is put in a larger context, it can be regarded as giving continuity to a certain version of national identity reproduced through food consumption. Estonians, it can be understood, have managed to adapt to modernity and take advantage of scaled economies while leaving space for smaller businesses and keeping traditions alive. This can be observed, for instance, in the description of the bread industry:

The first Estonian bread industries were established already in the 19th century and Estonia's oldest bead industry, Leibur, is already more than 250 years old. The industries today manufacture around $90 \%$ of the entire Estonian bread production, however, the number of 
small bakeries and farms whose produce ends up on supermarket shelves is also on the rise, as they offer variety.6. (https://www.eestitoit.ee/en/content/bread)

Regardless of the fact that many national restaurants serve daily pelmeenid (in Russian pelmeny), seiljanka (in Russian solyanka), and pancakes, the website offers succulent stories about the love used to prepare all the ingredients and harmony with an Estonian countryside that generously offers its fruits for the best Estonian recipes, from forest mushrooms to honey and dairy products. In line with this narrative, the political elites' conceptions of the Estonian nation dictate national food ingredients, symbols, and practices with which Estonian citizens might associate themselves and through which the imagining of the Estonian nation might be facilitated. In contrast to Soviet practices of mass-production and industrialization, Estonia is depicted as a country of small family businesses producing, in limited quantity, high-quality products.

Critically looking at this narrative, our team set out to explore to what extent ordinary citizens endorsed this version of Estonian-ness on two levels. One is ideological: whether informants somehow agree with state definitions of these markers, identify themselves with them, or at least if they feel close to these narratives. The other level is practical. Do Estonians actually live the way they are described by state narratives, striking a balance between the modern and the traditional, the smart and the suggestive, and is this life model viable in reality? Is it really possible to eat "true Estonian, local, genuine" on the average budget of an Estonian household? When asking informants about what they think is typical of their national cuisine, three main streams emerged: post-Soviet, nouvelle, and international cuisine. The first could be considered the continuation of Soviet food. In the words of an informant:

"In my family cooking is something we do as a means of socialization. My father, a sailor, likes a lot to cook when he's spending time with us. Every time he is back we can feel his presence from the kitchen. He likes to go to the market, he knows where to buy the best fish. There's a bazaar twice a week with fresh fish and he'll prepare some gorgeous food. Apart from fish, perhaps his firmennoe bludo [chef's special dish] is pelmeny. He lived in Siberia and says that this is where he learned to cook them properly. The secret of good pelmeni is in the proportion of meat used for the filling. You must mix at least two kinds of meat and one-third of the farsh must be mutton meat. When preparing pelmeny, we make a lot and eat a part of them. We freeze the rest. We put 150 pieces on each cooking paper and then to the freezer for the next time. Now we are somehow losing the habit, we prefer to make khinkali (Georgian dumplings) that are bigger and feed you quicker, so one needs to prepare fewer of them (and spend less time)."(Olena, Russian, 38)

It is important to notice that, even if the above informant gave a continuation to Soviet traditions, the relationship of Estonians with solyanka, borshch, or bliny can be defined as "banal" (Billig 1995). When hungry in a cafe or cooking at home, there will be little "ethnic distinction" between dishes. If today a $u k h a$ is served and you feel like eating it, it is not that important that this is somehow a Soviet heritage. Estonian local cuisine is, by inception, relatively simple. It comes from what was available in the continental Nordic climate and what the soil could provide. The evolution of Estonian cuisine has been standardized on the website of Estonian food, but it is constantly ongoing. Some of the informants would mention, as typical Estonian food, a number of simple ingredients ranging from potatoes to meat, rye bread, and soups. These ingredients have been integrated with what has become easily available thanks to globalization. For instance, an informant reported: "When I eat out of Estonia I tend not to order salmon or redfish in general. This is because it is so common to eat it in Estonia ... we actually eat too much of it, being relatively inexpensive, that if I have a choice I want to eat something different" (Kadri, 32, Estonian).

The desire for experimentation and the proximity of Scandinavia-where a trend of nouvelle, or Nordic cuisine, has become increasingly popular over the past several years, have led to an increase 
in the diversity of dishes that you can find in restaurants. Experimentation is mostly visible in restaurants, whilst at home, according to several informants, they tend to be more "conservative" and prepare simpler things. Indeed, Tallinn has been mushrooming with eat-out places and with attempts, more or less successful, to re-propose traditional ingredients innovatively. Several informants highlighted the general thirst for modernity in the country that is particularly visible in the culinary sector. A growing number of Estonian restaurants present dishes in a rather sophisticated way, spelling out every single ingredient, no matter how small the quantity in the recipe. But in the end, the basis is very simple, because Estonians tend to stick to what they know and to their basic ingredients. Because some of the local foods have been re-evaluated as super foods, they are now used in a novel way to promote something healthy and Estonian but with a modern or Western twist. This is the case with buckwheat risotto that is nothing but the revisiting of a Soviet dish ( grechka) with some attractive ingredients added but that has nothing to do with risotto. Which brings us to the limits of this attitude:

These new places with healthy food or offering nouvelle cuisine are not for the average Estonian. They are expensive and often unaffordable. You can go there for a very special occasion, but they are not for the everyday. If you need to eat out at lunch many places are offering a business lunch, affordable but much simpler than that in the end. We like to think of ourselves going to a farm to buy homemade goods, eat healthily and in harmony with nature. But the reality is that ordinary people cannot afford to buy there. But they can, of course, go to their country house and make their own jars of marinated vegetables or jams. (Kerli, 27, Estonian)

International cuisine is something that has exponentially gained popularity in Estonia in the past ten or so years. The number of Estonian cafes serving various kinds of pasta, tom yum soup, or tacos grows everyday. It is also not uncommon to have enchiladas or chili con carne served at university canteens. But all this has two limits. First, this thirst for exotic food is present as long as customers can remain within their comfort zone. Indian and South Asian restaurants are relatively common, but even the spiciest items on their menu will taste mild to a South Asian customer. And even these restaurants leave some international items on their menu for the customers that are reluctant to try things that look too new or too different. Second, in spite of their availability, the variety of foods that are consumed is limited. The owner of a relatively expensive Italian restaurant, where you would go for a special occasion, explained:

I have excellent fish served here and a number of sophisticated dishes. But they are mostly for the Italians or people with a special taste. Otherwise, the things that I sell the most are bolognese and carbonara, possibly the quintessence of the imagined Italian cuisine in the world. People here do not want to try new things but they come for the pleasure to feel that they are in an Italian restaurant. (Mario, restaurant owner 33)

Restaurants are selling modernity but at a price. The price of food in restaurants is high, compared to the average salaries in the country. It is nice to be able to enjoy a good atmosphere and eat some novel dishes, but this is far from accessible to everyone. As an informant reported:

Young kids would go and eat there because they can, and because they feel proud to eat what they believe is Estonian food. Otherwise, normal people with a normal state of mind understand that these microscopic portions served in large dishes with cool names and ingredients are not worth even 1/3 of their selling price. (Martin, 30, Estonian)

On the one hand, we can see the state narrative suggesting what "real Estonia" is and what "real Estonians" eat. This is an idyllic picture, accompanied by high-quality photos and endorsements by public figures of the country. On the other hand, however, these images and food are either unaffordable to most of the people as daily food, or just difficult to understand and identify with. It is 
good to go to a good restaurant or eat healthy food to celebrate some special occasion, but every day Estonian eating, in the house or out, is composed of simple ingredients and a mix of local and Soviet culinary traditions, as the next section also illustrates.

\section{Estonian Products: Identity (Un)packing}

Beyond state-driven narratives, and surfing on the wave of these deep efforts, private and market actors have started expanding the scope and the role of food in Estonia. An Estonian food museum was opened in 2017 and many companies have started encouraging what we have called "patriotic consumption" (Polese and Seliverstova 2019) to appeal to people who feel proud to reproduce state narratives on their kitchen table. The local food industry often promotes its products through the use of national symbols in two main ways. One is to decorate the package with national patterns or colors. The other approach has suggested using catchy and evocative words when describing the product. Words like: "authentic," "ecologically pure," "with no preservatives," or with "real" and "native" flavor are widely used. This strategy gives continuity to the attempts to create associations between Estonia and its inhabitants by labeling the country as technological but committed to nature and confirming the special relationship that Estonians allegedly have with nature (Polese and Pawlusz 2017b). This construction of patriotic food can be regarded as something incepted by entrepreneurs from the business sector but matching state-led attempts to create a relationship with food, its production, and its marketing. Marketing of "patriotic food" takes advantage of packaging embellished with elements taken from national narratives and "Estonian history and traditions" but it opens the door to patriotic consumption by "de-exclusivizing Estonian-ness." If, for nationbuilding, language and ethnic belonging can make Estonian identity restricted to a circle of people who can display them at social occasions, and limit the rights of others to feel Estonian, consumption enlarges the circle of people showing support for Estonia. It becomes thus possible to ascribe to some of the most important national values (i.e. committed to produce genuine and natural food) by simply buying - into a narrative (literally) constructed by a variety of actors.

Through a synergy with state narratives on food production and consumption, foods are often promoted through the use of national symbols by using evocative colors and words. For instance, the firm Alma, produced a carton of standard milk which, in 2015, was emblazoned with a printed ribbon in the national colors of the Estonian flag (see Figure 1). The packaging used for Estonia's traditional rye bread is also commonly decorated with elements coming from Estonian folklore, like traditional embroidery patterns, images of flowers and animals, and anthemed in Estonian folk songs (see Figure 2).

By packaging products in suggestive ways and promoting the association of healthy-localEstonian, food producers contribute to influencing people's choices and their everyday consumption. This results in the formation of narratives with different degrees of rupture with the past. In several cases, informants highlighted the change between Soviet and modern Estonia. As an informant put it:

In Soviet times we used to bring things to the countryside, now we do the opposite and people understand the importance of fresh and genuine food. But we mostly buy from specialized farms that guarantee certain standards. I can shop in supermarkets, but my eggs and milk come from X [name of a company] so I am sure they are always good. (Anna, 32, Russian)

Various informants, in the end, suggested that several countryside farms have been renovated and modernized to produce bio and organic goods. On the one hand, they could be regarded as tourist attractions, since they often sell at higher prices. However, on the other one, they provide customers with the guarantee to eat local, genuine, and, to put it directly, "Estonian." Food is handpicked, homemade and you can also enjoy it in pleasant and calm surroundings, in case you decide to stay for lunch. If you can afford this, the experience is likely to be worth the trip. In contrast, some 


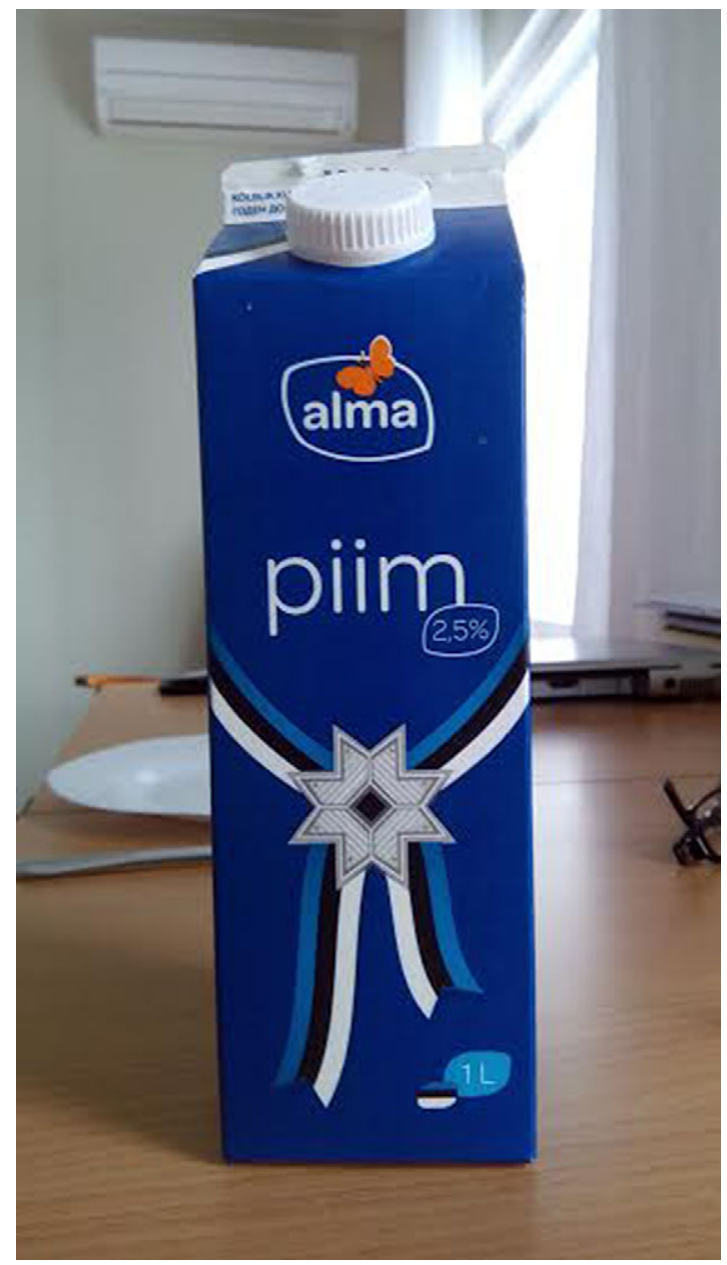

Figure 1. A carton of standard milk emblazoned with a printed ribbon in the national colors of the Estonian flag.

informants were more critical. For instance, an informant reported that things, in practice, got worse:

I am from X (a few kilometers below Tallinn), where we had everything in Soviet times. Estonia was an agrarian country and we were able to produce whatever we needed, except for kolbaski (sausages). We applied rotation of cultures not to impoverish the land, kapustu zakvaschivali. Our cabbage is the best one, not the Dutch one that we eat now. We grew cucumbers, tomatoes and...good people [meaning that good societal values were widely conveyed and accepted]. Everyone recalls those times and would like to get this back. They were used to produce what was needed; but in the past years, more and more products started appearing in shops so people started thinking: why we need to do all those efforts if we can buy everything at reasonable prices in supermarkets? Now we can even find cherries, not really an Estonian product. Nowadays people got lazy. I would call it "lost generation" of those who grew up after the end of the USSR. (Sergey, 49, Russian)

Estonia, and even more its capital Tallinn, is a place where the food industry, and the restaurant scene, has grown exponentially and evolved in several directions. A restaurant owner noticed that it 


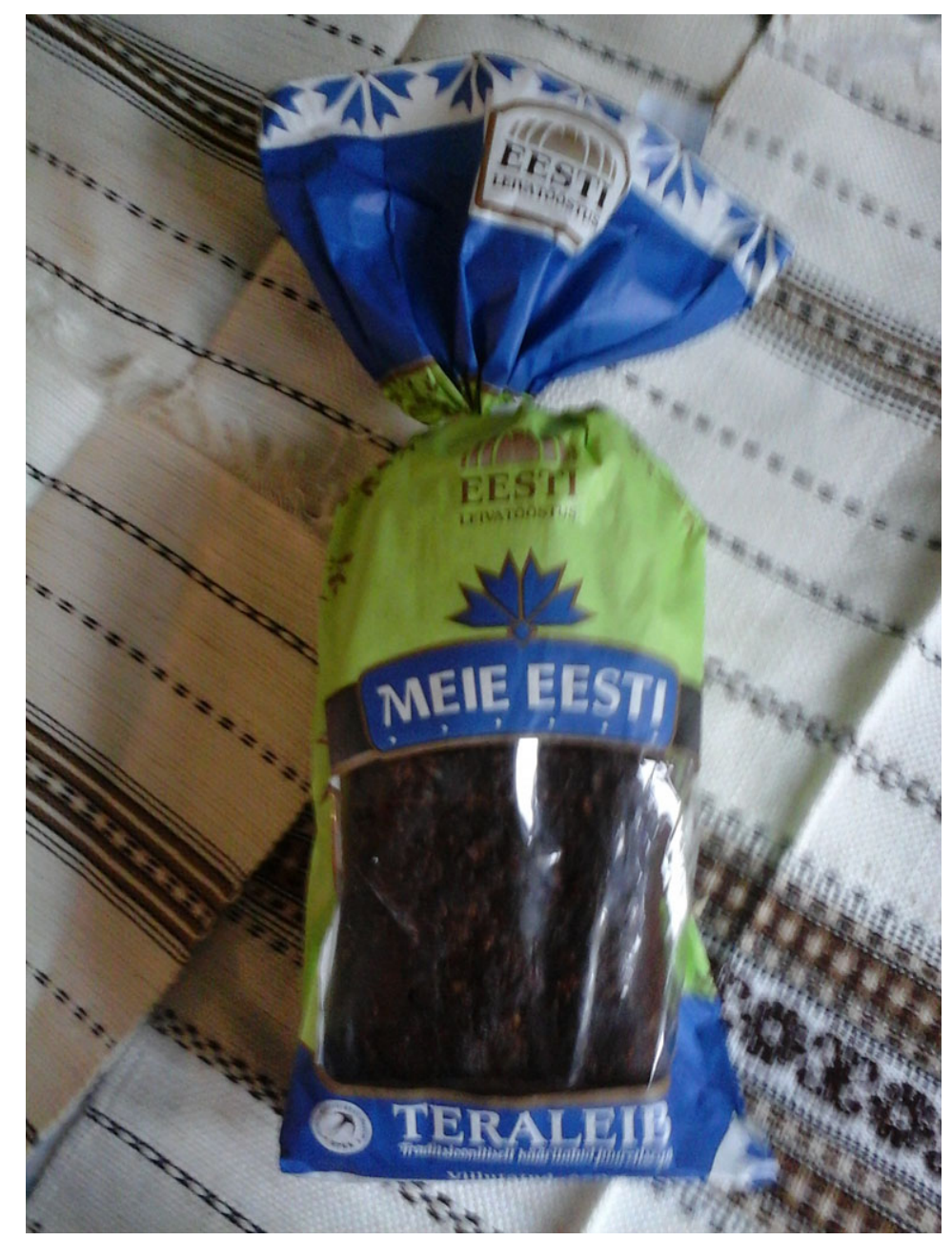

Figure 2. Packaging used for Estonia's traditional rye bread decorated with elements coming from Estonian folklore, such as traditional embroidery patterns, images of flowers, and animals sung about in Estonian folk-songs.

is now very fashionable in Tallinn to have a restaurant decorated with tables and chairs that are all different. In his view, this could be some sort of rejection of the Soviet period where everything was made to look the same everywhere. In addition, the current trend for things that look old, undecorated, or naked (like unpainted walls) could also be a reaction to the Soviet emphasis to standardize and sterilize public places. Tallinn, and in general Estonia, have developed a desire to discover and try new things. An informant reported: "When we eat out, we tend to look for new places. We check gastronomic guides to see what are the trendiest places, the places where you need to go. The atmosphere is important and we have more and more places that inspire you and where you seem to enter a new world," (Triin, 31, Estonian).

The Telliskviri area, near the railway station, is perhaps the best example of this new tendency. Once a decayed neighborhood, it is now one of the trendiest places to go, where you will find restaurants and cafes serving a variety of novel dishes, variations on international dishes, and where you can buy Estonian craft beer for five or six Euro a bottle. You will have the chance to drink inside an industrial complex reconverted into a large trendy cafe, or inside a tram or train that has been transformed into a brewery. A few steps away you have the Balti Jaama Turg, the old railway bazaar 
that has been completely modernized. Once harboring kiosks and older people selling second-hand goods, it is now filled with posh cafes and shops. This thirst for modernity, and rupture with the past, can reach paradoxical levels. For instance, one of the authors noticed that in a recent exhibition on Soviet Estonia, kitchens organized in a way that you can easily still find in Estonia were depicted as belonging in the past. Marmalade jars and pots with marinated vegetables were displayed in the exhibition room like they were things to save from oblivion (Polese 2019). This was presented as historical, even though several informants said they have regular access to such jars in their grandma's kitchen. As an informant put it: "Yes, we do lots of things at home but this has never been a matter of money. We do it because it's there. We have some berries and here is marmalade, we find mushrooms and we dry them. I personally never related this to financial situations or ideology, it was just the natural thing to do," (Natasha, 43, Russian).

National food narratives are certainly felt closely by a growing number of Estonians. But to "abide by all the rules," that is, to buy products only produced by local farms, decorated with national colors, and allegedly homemade or handpicked, is virtually impossible. On the one hand, these patterns of consumption only partly match cultural preferences. However, on the other one, behavioral economics shows that a public can be "educated" into buying certain products and consumer choices may be influenced to a fair degree. The price of most of these products remains so high that, even the most diligent citizen, or one that buys into such narratives, faces the limits of their monthly budget, not allowing them to perfectly comply with all the narratives. What results from these two forces is a hybrid model of consumption and acceptance of consumer patterns that also reflects an identity that is negotiated through everyday consumption by citizens.

\section{Discussion: Biting Identities}

Citizens, or at least inhabitants, of Estonia can buy genuine, local, natural, homemade, and national and prioritize any of the above words when choosing a product, a restaurant, or a dish. In some respects, it is more interesting, at least to us, how-and why-they buy rather than what they buy. If a suggestion of buying "Estonian" might sound like a request for political support, the suggestion to buy local sounds more like supporting the imagined community of your neighbors and those working for the economy of your country so that you can have a job. The suggestion to buy genuine, in contrast, is a suggestion to take care of your health and, by doing this, perhaps thank the land that is giving you this chance.

This has also been supported by other studies. It has been shown that Russians often display a dual attitude. From one side they might continue to blame the state for depriving them of various rights and for disrespecting Russian language and culture. When commenting upon life in Russia (how they see it during their short trips or how they imagine it generally) they often express a form of gratitude toward the country they live in, emphasizing that they would not have similar opportunities elsewhere (Cheskin 2013). This appears to belie the duality that faces many Russian speakers in Estonia. They appear to feel loyalty toward the opportunities the state provides more than to the state itself. As such, it is possible to separate the institutional framework, wherein they live their everyday life, from general societal acceptance and integration (Seliverstova 2017; Seliverstova and Pawlusz 2016).

Ultimately, it is possible to conceptualize "two Baltic regions," both in literature and practice (Polese et al. 2017), each focused on a distinct realm of practice and discourse within the region. In the first realm, an emphasis is put on citizenship rights, political participation, and formal access to opportunities provided by the state. Lack of support from the state is thus equated with discrimination and the subsequent absence of various opportunities for the Russian national minority. In the second realm, a thin but growing number of scholars are starting to observe how Russians perform their own, everyday identity construction. This everyday perspective challenges us to at least reconsider the overwhelmingly negative representations of integration practices that emanate from institutional and political approaches. Eventually, this perspective permits us to appreciate an 
interesting dualistic attitude, conciliating rejection of a political identity with acceptance, or even promotion and pride in, some identity markers that may be associated with the geographical territory where Estonia lies. We recall here the case of a respondent who, despite having been granted Estonian citizenship and speaking good Estonian, did not consider himself Estonian. A sort of transformation happened for him when travelling abroad, after which he started associating Estonia with local dairy products that were fresh, tasty, and available in a large variety. This attitude eventually made him feel proud of Estonia, allowing him to choose some alternative markers for his Estonian identity. His attitude showed some desire to reject Estonian-ness as constructed by the state, or at least some ideas on Estonian identity. However, his attitude, behavior, and consumer practices were showing a certain degree of attachment to some aspects of Estonian-ness. He was in practice accepting some cultural and identity markers proposed by non-state actors (in this case the business sector) with little or no connection to national narratives, but still linked to a sense of belonging. The case of the above informant was not isolated. In practice, it was possible to identify a tendency showing that the pride of having "the best dairy products" or "real black bread with no colorants" can indeed unite larger portions of the local population in a de-politicized fashion that the national flag or other official symbols cannot guarantee.

It has been argued that both groups, Estonians and Russians, think that their consumer behavior is common among Estonian citizens (Polese and Seliverstova 2017). Both communities seem to convey a message that they are behaving according to what they perceive being "national standards" or "respecting national values." This body of research shows that individuals appear to claim that they are consuming local and national products, building houses and living the way that is traditional "here." Such practices, therefore, are conceptualized as validation and respect for the traditions of a land and its people. The difference might be that, while Estonians refer to the traditions by a population (a nation in a Walker Connor fashion), Russians refer to the local (land, territorial) traditions as preeminent in a sort of civic or economic nationalism. They seem to be performing and reproducing ethnic and civic ideas of a nation that are only in competition discursively. In reality, they are creating a sense of belonging to a particular citizenry, associated with certain values, understanding of traditions and the past alongside various other identity markers. It could even be said that while there is potentially a competition in politically-propagated discourses, in reality, there are just different ways to experience national belonging, which can exist in parallel and are not mutually exclusive. Ordinary people come to play an important role in imbuing food products and practices with symbolic national meanings (Cusack 2000). Foods divide but food also unites communities. As an informant, a manager of a small farm, put it:

We have basically no difference between Estonians and Russians, the garden unites us! We both like natural food and to eat well, we are much closer than we'd like to admit...The difference is, perhaps, that Estonians are more conservative, they want the old taste, Russians like to make experiments, mix. I once spoke with a seed wholesale seller: I would buy 120 different kinds of seeds, but the average Estonian only three. (Sergey, 49, Russian)

The growing presence of these foods, and this mode of branding, creates patterns of consumption associating food and homeland. If everyday actions reinforce the sense of belonging to the nation (Billig 1995) then everyday food consumption might be working in this direction (Foster and Özcan, 2005; Wilk 1999) and thus reinforce a sense of attachment to the homeland and, in turn, to a state. Nakano (2004) associates economic performance with a sense of pride in belonging to a given economic community and, in turn, to a national one. In line with this we could associate the production and consumption of healthy foods with national pride, a thing that can be felt, and lived by representatives across various linguistic and ethnic communities. This is not to say that people could overcome a sense of exclusion or discrimination by simply buying genuine and healthy bread. However, this is a territory where Estonian citizens meet, sometimes unintentionally, regardless of their origins and political credo. 
This reflects, on the other hand, a tendency that sees a majority of Russian speakers (across all three of the Baltic states) prefer to maintain overlapping nodes of identification, embracing various elements associated with Russian, Baltic (Estonian, Latvian, Lithuanian), and Soviet cultures (Cheskin 2016; Kemppainen et al. 2004; Pisarenko 2006; Kasatkina 2006). It also results in the production of a so-called hybrid identity, incorporating values promoted by a civic identity, which local Estonian (but also Latvian or Lithuanian to some extent) ethnocultural identities are arguably short of. Russian speakers become the performers of an identity, perceived by them as national, which is more open and is more supportive of the state vision of the nation.

\section{Conclusion}

The politicization of the minority question in the Baltics has often led to an over-representation of formal channels of identity building and this has come at the expense of an (unrepresented) everyday dimension of integration and national identity. While agreeing that the state, and its political elites, have a large degree of maneuver in proposing identity markers, we suggest that these markers are not necessarily and automatically accepted by the totality, or even majority, of a population. They can, indeed, be renegotiated and some of them end up then partly or totally rejected. Agency, in other words, matters. Accordingly, ordinary citizens can be more readily considered as active contributors to the creation, identification, and proliferation of (alternative) elements of national identity. Even more important, our empirical evidence points at the possibility that people themselves can identify markers and engage with behaviors that, although not included in official identity narratives, eventually contribute to the construction of a narrative on identity that is not necessarily in line with the elite-driven nation-building project.

In this article, we have made a case for expanding the parameters for academic scrutiny of national identity construction in Estonia. The long-standing emphasis on top-down institutional and political approaches to integration, although useful to grasp the national narrative, we argue, often obscures the multifaceted ways in which integration actually occurs at the everyday level of interaction. By broadening the scope of integration to include more "banal" forms of consumer practices, it becomes possible to investigate integration at the lived and micro level. While there might be a tendency to ignore or dismiss these practices as insignificant, it is here that individuals have the latitude to perform their national identities in complex and less rigidly-determined ways.

If the ultimate goal of any nation-building program is to unite a group of individuals around a set of norms and practices associated with a political, territorial, or cultural space, then consumer practices offer one of the most promising modalities for this to occur. Food consumption, for example, presents an example of how individuals from various socially-constructed groups can share common experiences that link them to national spaces. For our given examples, taking pride in the quality of Estonian bread does not contradict ethnic categories of identity or belonging which often compete within the political sphere.

Even though marketing and branding strategies are often constructed on the basis of well-known ethnic tropes, consumption offers a less politicized sphere, focusing as it does on individual choice. This proffers a more readily accessible means for individuals to enjoy access to ethnic practices that are often institutionally and politically prohibitive. Civic views of nationalism are commonly defined in terms of voluntarism as opposed to essentialism (Breton, 1988). The case of consumer nationalism demonstrates how ethnic nationalism can be transformed into a voluntary, and therefore civic, nationalism. This does not mean, however, that differences cannot be observed among patterns of majority and minority group behavior or attitudes. While consumer nationalism presents evidence of a more democratic performance of national belonging, we also see hints of subtly differing patterns of consumer practices. Certainly, these require more academic attention. However, by examining identity through the prism of consumer practices and banal forms of nationalism, we can present a far less bleak view of social amalgamation in the Baltic states. Along 
with this axis of consumer behavior and everyday lived-experience, Estonians and non-Estonians share a wide range of commonalities which are all too often ignored.

Our study can be used to claim that everyday practices should be revisited. Analyses of everyday practices should take into account instructions from the top, the way they are passed to the target groups, but also the agency of the target group, and other informal actors, in the negotiation, redefinition, or even rejection of identity markers and attitudes. This is a difficult task that risks being biased by subjectivity or lack of information, and this has been behind our choice to involve several authors for this single study but also to look at several sources where identity is narrated, reproduced, and possibly renegotiated. However, consumption, and in particular food consumption, is an area allowing good observations when combined with the everyday. First, nobody is immune to it. To survive you need to eat and to eat you usually need to buy. Choosing to consume and not consume certain products may be regarded as highly embedded in political choices in the case of boycotts but is not necessarily political in its common and everyday use. Yet, the aggregate of these attitudes allows for the observation of societal tendencies that are quite telling about what a society likes or not. Whilst the question on how many units of cottage cheese have been consumed in a given place over a given period may interest marketing specialists, the meaning of choosing to consume, or not, cottage cheese (and from a particular brand) can say a lot on the attitude some people have, especially if we learn the most common associations between that particular cheese and widely accepted cultural references. By force of this, if politicized marketing-attempts by the state, and its agency, to promote a certain (national) product, can be regarded as state instructions, whether ultimately people decide to consume more or less of that product is an individual choice, and the reasons why people do that can be investigated through qualitative methods.

Acknowledgments. The final version of this article was prepared during Dr Polese's stay at the Aleksanteri Institute of the University of Helsinki. The author would like to thank the Institute for the invitation and the work-friendly environment local colleagues provided during his stay.

Financial Support. The initial research for this article has been possible thanks to support from the European Commission FP7-MCA-ITN-2012 “Tensions”, GA 316825). Further processing of the material has been made possible thanks to Dublin City University's Faculty of Humanities and Social Sciences' Journal Support Scheme (2019).

Disclosure. Authors have nothing to disclose.

\section{Notes}

1 Among other things, in the early 1990s, a significant number of Russians and Russian speakers were forced to accept the 'alien' status of non-citizens, or else apply for foreign citizenship (most commonly, Russian).

2 We are grateful to one of the reviewers who, by pointing at this issue as a potential weakness of the article, made us reflect and see the advantages of our approach.

3 While "Estonian" in Estonia refers to a native Estonian speaker, "Russian" may have a variety of meanings. It can certainly refer to an ethnic Russian inhabiting the country. But Russian is spoken by many other ethnic groups (Ukrainians, Belarusians) and in mixed families. In some cases, it can just indicate that the person lives in Estonia but is not a native Estonian speaker (although he or she might have good language abilities in Estonian). As a result, our classification for this article is linguistic rather than ethnic.

4 See "Where your grandma's kitchen belongs in a museum" at https://www.tol.org/client/article/ 28463-where-your-grandmas-kitchen-belongs-in-a-museum.html?fbclid=IwAR0UbDCVvSmC1nOVn8jB5_whil1nDfozRoUJtazsPaL9aEtpReLikKRKdo

5 https://www.eestitoit.ee/en/content/vegetables

6 https://www.eestitoit.ee/en/content/bread 


\section{References}

Aasland, Aadne \& Tone Fløtten. 2001. "Ethnicity and Social Exclusion in Estonia and Latvia." Europe-Asia Studies 53 (7): 1023-1049.

Aasland, Aadne. 2002. "Citizenship Status and Social Exclusion in Estonia and Latvia." Journal of Baltic Studies 33 (1): 57-77. Agarin, Timofey. 2010. A cat's lick: democratisation and minority communities in the post-Soviet Baltic. Amsterdam: Rodopi. Breton, Roman. 1988. “From Ethnic to Civic Nationalism: English Canada to Quebec.” Ethnic and Racial Studies 11(1): 85-102. Bauman, Zygmunt. 1998. Globalization: The Human Consequences. New York: Columbia University Press.

Barth, Fredrik. 1981. Process and Form in Social Life. London: Routledge \& Kegan Paul.

Belk, Russell. 1988. Possessions and Self. Oxford: John Wiley \& Sons, Ltd.

Billig, Michael. 1995. Banal Nationalism. London: Sage.

Bulakh, T. 2017. "Made in Ukraine: Consumer Citizenship during EuroMaidan Transformations." In Identity and Nation Building in Everyday Post-Socialist Life, 73-90. London: Routledge.

Brubaker, R. 1995. "National Minorities, Nationalizing States, and External National Homelands in the New Europe." Daedalus 124 (2): 107-132.

Caldwell, Melissa. 2002. “The Taste of Nationalism: Food Politics in Postsocialist Moscow.” Ethnos 67 (3): 295-319.

Caldwell, Melissa. 2004. Not by Bread Alone: Social Support in the New Russia. Berkeley, CA: University of California Press.

Caldwell, Melissa. 2004b. "Domesticating the French Fry: McDonald's and Consumerism in Moscow." Journal of Consumer Culture 4 (1): 5-26.

Chanet, J.F. 1996. L'école républicaine et les petites patries. Paris: Editions Aubier.

Cheskin, Ammon. 2013. "Exploring Russian-Speaking Identity from Below: The Case of Latvia." Journal of Baltic Studies 44 (3): 287-312.

Cheskin, A. 2016. Russian-Speakers in Post-Soviet Latvia: Discursive Identity Strategies. Edinburgh: Edinburgh University Press.

Connor, W., 1990. "When Is a Nation?” Ethnic and Racial Studies 13(1): 92-103.

Cusack, Igor. 2000. “African Cuisines: Recipes for Nation-Building?” Journal of African Cultural Studies 13 (2): $207-225$.

Datunashvili, Alisa. 2017. "The Georgian National Museum and the Museum of Soviet Occupation as Loci of Informal NationBuilding." In Polese et al. Identity and Nation Building in Everyday Post-Socialist Life. London: Routledge.

De Certeau, Michel. 1984. The Practice of Everyday Life. Trans. Steven Rendall. Berkeley, CA: University of California Press.

De Certeau, M., and Mayol, P. 1998. The Practice of Everyday Life: Living and Cooking. Minneapolis, MN: University of Minnesota Press.

De Soucey, M. 2010. "Gastronationalism: Food Traditions and Authenticity Politics in the European Union." American Sociological Review 75 (3): 432-455.

Douglas, Mary. 2002 [1979]. The World of Goods: Towards an Anthropology of Consumption. New York: Basic Books.

Douglas, Mary, and Baron C. Isherwood. 1996. The World of Goods: Towards an Anthropology of Consumption.London: Routledge.

Douglas, Mary. 2014. Food in the Social Order. London: Routledge.

Dunn, Robert. 2008. Identifying Consumption. Subjects and Objects in Consumer Society. Philadelphia, PA: Temple University Press.

Edensor, Thomas. 2002. National Identity, Popular Culture and Everyday Life. London: Bloomsbury Publishing.

Eglitis, Daina. 2002. Imagining the Nation: History, Modernity and Revolution in Latvia. University Park: Pennsylvania State University Press.

Ehala, Martin. 2009. “The Bronze Soldier: Identity Threat and Maintenance in Estonia.” Journal of Baltic Studies 40 (1): 139-158.

Elliott, Richard. 2004. "Making Up People: Consumption as a Symbolic Vocabulary for the Construction of Identity.” In Elusive Consumption, edited by K.M. Ekström and H. Brembeck, 129-143. Oxford: Berg.

Eriksen, Thomas Hylland. 1993. "Formal and Informal Nationalism.” Ethnic and Racial Studies 16 (1): 1-25.

Fabrykant, Marharyta. 2018. "Why Nations Sell: Reproduction of Everyday Nationhood through Advertising in Russia and Belarus.” In Informal Nationalism After Communism: The Everyday Construction of Post-Socialist Identities, edited by Abel Polese, Oleksandra Seliverstova, Emilia Pawlusz and Jeremy Morris. London: IB Tauris.

Foster, Robert John. 2002. Materializing the Nation: Commodities, Consumption, and Media in Papua New Guinea. Bloomington, IN: Indiana University Press.

Foster, Robert John, and Derya Özcan. 2005. "Consumer Citizenship, Nationalism, and Neoliberal Globalization in Turkey: The Advertising Launch of Cola Turka.” Advertising \& Society Review 6 (3). Published online at https://muse.jhu.edu/article/ 193863

Fox, Jon E., and Cynthia Miller-Idriss. 2008. “Everyday Nationhood.” Ethnicities 8 (4): 536-563.

Fox, Jon. 2017. "The Edges of the Nation: A Research Agenda for Uncovering the Taken-for-granted Foundations of Everyday Nationhood. Nations and Nationalism." 23 (1) 26-47.

Galbreath, D.J. 2005. Nation-Building And Minority Politics in Post-Socialist States: Interests, Influence And Identities in Estonia and Latvia. New York: Columbia University Press.

Gellner, E. (2008). Nations and Nationalism. Ithaca, NY: Cornell University Press. 
Gaufman, L. 2018. "Money Can’t Buy It? Everyday Geopolitics in Post-Soviet Russia." In Polese, Informal Nationalism After Communism: The Everyday Construction of Post-Socialist Identities, edtied by Abel Polese, Oleksandra Seliverstova, Emilia Pawlusz and Jeremy Morris. London: IB Tauris.

Giddens, Anthony. 1984. The Constitution of Society: Outline of the Theory of Structuration. Berkeley, CA: University of California Press.

Grigas, Agnia. 2014. “The New Generation of Baltic Russian Speakers.” EurActiv Opinions. November 28. https://www. euractiv.com/section/europe-s-east/opinion/the-new-generation-of-baltic-russian-speakers/. (Accessed August 29, 2016.)

Gudeman, Stephen. 2008. Economy's Tension: The Dialectics of Community and Market. Berghahn Books.

Hervouet, Ronan. 2003. "Dachas and Vegetable Gardens in Belarus Economic and Subjective Stakes of an" Ordinary Passion." Anthropology of East Europe Review 21(1): 159-168.

Herzfeld, Michael. 2005. Cultural Intimacy. London: Routledge.

Howard, Marc. 2003. The Weakness of Civil Society in Post-Communist Europe. Cambridge, UK: Cambridge University Press.

Hughes, J.N. and Kwok, O.M. 2006. "Classroom Engagement Mediates the Effect of Teacher-Student Support on Elementary Students' Peer Acceptance: A Prospective Analysis.” Journal of School Psychology 43 (6): 465-480.

Isaacs, Rico. 2015. "Nomads, Warriors and Bureaucrats: Nation-Building and Film in Post-Soviet Kazakhstan." Nationalities Papers 43 (3): 10151035.

Isaacs, Rico, and Abel Polese, eds. 2016. Nation-Building and Identity in the Post-Soviet Space: New Tools and Approaches. London: Routledge.

Iglesias, Julien. 2017. "Nuanced Identities at the Borders of the European Union: Romanians in Serbia and Ukraine." In Identity and Nationalism in Everyday Post-Socialist Life, edited by Abel Polese, Jeremy Morris, Emilia Pawlusz and Oleksandra Seliverstova 146-160. London: Routledge.

Jakobson, Valeria. 2002. “:The Role of the Russian-Language Media in Estonian Society.” Role of the Estonian Russian-Language Media in the Integration of the Russian-Speaking Minority into Estonian Society: 79. PhD dissertation available at https:// trepo.tuni.fi/handle/10024/67197. (Accessed 29 January 2020.)

Jacobson, Valeriya. 2006. “Русскоязычные как часть населения Эстонии: 15 лет спустя.” (Russian Speakers as Part of Estonian Population: 15 years after). Мир России. Социология. Этнология, 15(4).

Jordan, Paul. 2014b. Nation Branding: A Tool for Nationalism? Journal of Baltic Studies 45 (3): 283-303.

Kasza, Gregory. 2002. “The Illusion of Welfare 'Regimes.”' Journal of Social Policy 31 (2): 271-287.

Kasatkina, Natalya. 2006. “Adaptatsiia russkikh v kontekste etnicheskoi struktury sovremennogo obshchestva Litvy” [The Adaptation of Ethnic Russians in the Context of the Ethnic Structure of Contemporary Lithuanian Society]. Studia Slavica Finlandensia 23: 39-68.

Kerikmae, Tanel. 2001. "Estonian Constitutional Problems in Accession to the EU." In EU Enlargement: the Constitutional Impact at EU and National Level, edited by Alfred Kellermann. TMC Asser Instituut: The Hague, 291-300.

Kemppainen, Raija, Scott Ferrin, Carol Ward, and Julie Hite. 2004. “'One Should Not Forget One’s Mother Tongue': RussianSpeaking Parents' Choice of Language of Instruction in Estonia.” Bilingual Research Journal 28 (2): 207-229.

Knott, Eleonore. 2015. "Generating Data: Studying Identity Politics from a Bottom-up Perspective in Crimea and Moldova." East European Politics and Societies 29: 467-486.

Kolstø, Pal. 1996. “The New Russian Diaspora-an Identity of its Own? Possible Identity Trajectories for Russians in the Former Soviet Republic." Ethnic and Racial Studies 19 (3): 609-639.

Kolstø, Pal. 2016. Strategies of Symbolic Nation-Building in South Eastern Europe. London: Routledge.

Korts, Külliki. 2009. "Inter-Ethnic Attitudes and Contacts Between Ethnic Groups in Estonia." Journal of Baltic Studies 40 (1): 121-137.

Laitin, David. 1998. Identity in Formation: The Russian-Speaking Populations in the New Abroad. Ithaca, New York: Cornell University Press.

Lauristin, Marju, and Mati Heidmets. 2002. "Introduction: The Russian Minority in Estonia as a Theoretical and Political Issue." The Challenge of the Russian Minority: Emerging Multicultural Democracy in Estonia, 19-29.

Lefebvre, Henri. 1974. "La production de l'espace." L'Homme et la société 31 (1): 15-32.

Lefebvre, Henri. 1991. The Production of Space. Vol. 142. Blackwell: Oxford, UK.

Leping, K.O. and Toomet, O. 2008. “Emerging Ethnic Wage Gap: Estonia During Political and Economic Transition.” Journal of Comparative Economics 36 (4): 599-619.

Linz, Juan J., and Alfred Stepan. 1996. Problems of Democratic Transition and Consolidation: Southern Europe, South America, and Post-Communist Europe. Baltimore: MA. John Hopkins University Press.

Meckl, Markus, and Pascal Bonnard. 2007. "La gestion du double passé nazi et soviétique en Lettonie : impasses et dépassement de la concurrence entre mémoires du Goulag et d'Auschwitz." In L'Europe et ses passés douloureux, edited by Georges Mink and Laure Neumayer, 169-180. Paris: La Découverte.

Melberg, Hans Olav, Igor Munteanu, Claus Neukirch, Aleksei Semjonov, Alla Skvortsova, and Raivo Vetik. 2002. National Integration and Violent Conflict in Post-Soviet Societies: the Cases of Estonia and Moldova. Oxford, UK: Rowman \& Littlefield.

Menga, Filippo. 2018. Power and Water in Central Asia. Abingdon, UK: Routledge. 
Menga, Filippo. 2015. "Building a Nation Through a Dam: The Case of Rogun in Tajikistan.” Nationalities Papers 43 (3): 479-494.

Menga, Filippo. 2016. "Public Construction and Nation-Building in Tajikistan." In Nation-Building and Identity in the PostSoviet Space: New Tools and Approaches, edited by Rico Isaacs and Abel Polese, 193-205. Abingdon: Routledge.

Migdal, Joel., 2001. State in Society: Studying How States and Societies Transform and Constitute One Another. Cambridge: Cambridge University Press.

Mincyte, Diana. 2011. "Unusual Ingredients: Gastronationalism, Globalization, Technology, and Zeppelins in the Lithuanian Imagination." Anthropology of East Europe Review 29(2): 1-21.

Miller, Daniel. 1995. "Consumption and Commodities." Annual Review of Anthropology: 141-161.

Miller, Daniel. 2001. The Dialectics of Chopping. Vol. 1998. Chicago, IL: University of Chicago Press.

Morris, J., and A. Polese, eds. 2014. The Informal Post-Socialist Economy: Embedded Practices and Livelihoods. London and New York: Routledge

Mylonas, Harris. 2013. The Politics of Nation-Building: Making Co-nationals, Refugees, and Minorities. Cambridge: Cambridge University Press.

Nakano, Takeshi. 2004. “Theorising Economic Nationalism.” Nations and Nationalism 10 (3): 211-229.

Navaro-Yashin, Yael. 2020. Faces of the State: Secularism and public life in Turkey. Princeton: Princeton University Press.

Nimmerfeldt, Gerli. 2011. "Sense of Belonging to Estonia." in The Russian Second Generation in Tallinn and Kohtla-Järve: The TIES Study in Estonia, edited by Raivo Vetik and Jelena Helemae, 203-228. Amsterdam: Amsterdam University Press.

Morris, Jeremy. 2012. "Learning How to Shoot Fish on the Internet: New Media in the Russian Margins as Facilitating Immediate and Parochial Social Needs." Europe-Asia Studies 64 (8): 1546-1564.

Ó Beacháin, Donnacha, and Kevlihan, Rob. 2013. “Threading a Needle: Kazakhstan between Civic and Ethno-Nationalist StateBuilding." Nations and Nationalism 19 (2): 337-356.

Ó Beacháin, Donnacha. 2016. "Nation-Building and Elections in an Unrecognised State: The Case of Abkhazia." In NationBuilding and Identity in the Post-Soviet Space: New Tools and Approaches, edited by R. Isaacs and A. Polese, London: Routledge, 206-225.

Ó Beacháin, D., and A. Polese, eds. 2010. The Colour Revolutions in the Former Soviet Union: Successes and Failures. London: Routledge.

Onken, Eva-Clarita. 2007. “The Baltic States and Moscow's 9 May Commemoration: Analysing Memory Politics in Europe.” Europe-Asia Studies 59 (1): 23-46.

Pawłusz, Emilia, and Oleksandra Seliverstova. 2016. "Everyday Nation-Building in the Post-Soviet Space: Methodological Reflections." Studies of Transition States and Societies 8 (1): 69-86.

Pawłusz, Emilia. 2017. "The Estonian Song Celebration (Laulupidu) as an Instrument of Language Policy." Journal of Baltic Studies 48 (2): 251-271.

Pawlusz, Emilia, and Abel Polese. 2017. “'Scandinavia’s Best Kept Secret': Tourism Promotion as a Site of Nation-building in Estonia (with a Free Guided Tour of Tallinn Airport.” Nationalities Papers 45 (5): 873-892.

Pechurina, Anna. 2015. Material Cultures, Migrations, and Identities: What the Eye Cannot See. London: Palgrave Macmillan. Pechurina, A. 2017. "Post-Soviet Russian-Speaking Migration to the UK: The Discourses of Visibility and Accountability." In Post-Soviet Migration and Diasporas, 29-45. London: Palgrave Macmillan.

Pettai, Vello, and Marcus Kreuzer. 1998. "Party Politics in the Baltic States: Social Bases and Institutional Context." East European Politics \& Societies 13 (1): 148-189.

Perchoc, Philippe. 2010. “Les Mutations Du Compromis Mémoriel Européen. Un Exemple Balte." In Le Passé Au Présent. Gisements Mémoriels et Actions Historicisantes En Europe Centrale et Orientale, edited by Georges Mink, 55-68. Paris: Michel Houdiard editeur.

Pisarenko, Olga. 2006. "The Acculturation Modes of Russian Speaking Adolescents in Latvia: Perceived Discrimination And Knowledge Of The Latvian Language.” Europe-Asia Studies 58 (5): 751-773.

Polese, A. (2010) "The formal and the Informal: Exploring 'Ukrainian' Education in Ukraine, Scenes from Odessa," Comparative Education 46 (1): 45-62.

Polese, Abel. 2011. "Language and Identity in Post-1991 Ukraine: Was it Really Nation-Building?" Studies of Transition States and Societies 3(3): 36-50.

Perchoc, Philippe, 2012. “'Une tribune pour l'Europe.' Pratiques et usages du discours européen au Collège d'Europe.” Histoire@ politique (2): 130-148.

Polese, A., and Kevlihan, R. 2015. "Locating Insurgency, Informality and Social Movements on a Spectrum: Is There a Theory Linking Them All." Paper presented at the 9th Pan-European Conference on International Relations, Giardini Naxos, Sicily. Italy. , September 23-26.

Polese, A. (2009) “Une version alternative de la 'révolution orange': Transformations identitaires et 'nation building spontané.” Socio-logos 4. http://socio-logos.revues.org/2315 (online only)

Polese, A., T. Ambrosio, T. Kerikmae, and O. Seliverstova. 2020. "Small Countries and New Voices: Nation Branding and Diplomatic Communication in Estonia.” Mezinarodny vztahy/Czech Journal of International Relations 55 (2): 24-46. 
Perchoc, P., 2013. "Les États baltes, entre défense territoriale et élargissement des concepts de sécurité." Revue detudes comparatives Est-Ouest 3: 61-88.

Perchoc, Philippe. 2014. “Un Passé, Deux Assemblées. L'assemblée Parlementaire Du Conseil de l'Europe, Le Parlement Européen et L'interprétation de L'histoire (2004-2009).” Revue D'études Comparatives Est-Ouest. 45(3-4): 205-235

Perchoc, Philippe. 2015. "Negotiating Memory after the Enlargement in the European Parliament." European Review of International Studies 2 (2): 2-14.

Pfoser, Alena. 2014. "Between Russia and Estonia: Narratives of Place in a New Borderland." Nationalities Papers 42 (2): 269-285.

Polese, Abel. 2010. "The Formal and the Informal: Exploring 'Ukrainian' Education in Ukraine, Scenes from Odessa." Comparative Education 46 (1): 47-62.

Polese, Abel, and Slavomir Horak. 2015. "A Tale of Two Presidents: Personality Cult and Symbolic Nation-Building in Turkmenistan.” Nationalities Papers 43 (3): 457-478.

Polese, Abel, Oleksandra Seliverstova, Emilia Pawlusz, and Jeremy Morris, eds. 2018. Informal Nationalism After Communism: The Everyday Construction of Post-Socialist Identities. London: IB Tauris.

Polese, A., T. Kerikmae, O. Seliverstova. 2018. "Estonie: la diplomatie du marketing national." Hermes 81: 64-71.

Polese, Abel, Oleksandra Seliverstova, Emilia Pawlusz, and Jeremy Morris, eds. 2017. Identity and Nationalism in Everyday Post-Socialist Life. London: Routledge.

Polese, Abel, Oleksandra Seliverstova, Emilia Pawlusz, and Jeremy Morris. 2017b. "On Informal and Spontaneous Identities." In Identity and Nationalism in Everyday Post-Socialist Life, edited by Abel Polese, Jeremy Morris, Emilia Pawlusz and Oleksandra Seliverstova London: Routledge.

Polese, Abel, and Emilia Pawlusz. 2017. "Nation Branding and Nation Brochuring: Building Identity in Estonia, Baltic Worlds." http://balticworlds.com/wp-content/uploads/2017/11/Baltic-Worlds-3-2017-uppslag.pdf.

Polese, Abel, and Emilia Pawlusz. 2017b. "Branding a Nation." Transitions Online. June 7, 2017. http://www.tol.org/client/ article/26970-estonia-tourism-branding-nation-identity.html. (Accessed 10 December 2019.)

Polese, A. (2019) “Estonia: where your grandma's kitchen belongs in a museum". Transitions online 27 June https://www.tol. org/client/article/28463-where-your-grandmas-kitchen-belongs-in-a-museum.html?fbclid=IwAR0UbDCVvSmC1nOVn8jB5_whil1nDfozRoUJtazsPaL9aEtpReLikKRKdo.

Polese, Abel, and Oleksandra Seliverstova. 2019. "Luxury Consumption as Identity Markers in Tallinn: A Study of Russian and Estonian Everyday Identity Construction Through Citizenship.” Journal of Consumer Culture 20 (2): 194-215.

Rodgers, Peter. 2007. “Compliance or Contradiction? Teaching 'History' in the 'New' Ukraine. A View from Ukraine's Eastern Borderlands.” Europe-Asia Studies 59 (3): 503-519.

Rudé, George, and Eric J. Hobsbawm. 1968. Captain Swing. New York: Pantheon Books.

Richardson, Tanya. 2008. Kaleidoscopic Odessa: History and Place in Contemporary Ukraine. Toronto: University of Toronto Press.

Seliverstova, Oleksandra. 2017. “Consuming National Identity in Western Ukraine." Nationalities Papers 45(1): 61-79

Scott, James, 1985. Weapons of the Weak. Everyday Forms of Peasant Resistance. New Haven: Yale University Press.

Scott, James. 2014. Two Cheers For Anarchism: Six Easy Pieces on Autonomy, Dignity, and Meaningful Work and Play. Princeton: NJ, Princeton University Press.

Siiner, M., 2006. "Planning Language Practice: A Sociolinguistic Analysis of Language Policy in Post-Communist Estonia." Language Policy 5(2): 161-186.

Skey, Michael. 2011. National Belonging and Everyday Life.Houndsmill Basingstoke: Palgrave Macmillan.

Skey, Michael. 2015. “'What Nationality He is Doesn't Matter a Damn!' International Football, Mediated Identities and Conditional Cosmopolitanism.” National Identities 17 (3): 271-287.

Smith, Graham. 1996. The Ethnic Democracy Thesis and the Citizenship Question in Estonia and Latvia. Nationalities Papers 24(2): 199-216.

Strzemanska, Aneta. 2017. "Formal and Informal Nationalism. Jazz Performances in Azerbaijan." In Identity and Nation Building in Everyday Post-Socialist Life, edited by Abel Polese, Jeremy Morris, Emilia Pawlusz and Oleksandra Seliverstova London: Routledge.

Trentmann, Frank 2007. “Citizenship and Consumption.” Journal of Consumer Culture 7 (2): 147-158.

Veblen, Thorstein. 2017 [1899]. The Theory of the Leisure Class. London: Routledge.

Vetik, Raivo, and Jelena Helemäe. 2011. The Russian Second Generation in Tallinn and Kohtla-Järve: The TIES Study in Estonia. Amsterdam University Press.

Vihalemm, Triin, and Veronika Kalmus. 2009. “Cultural Differentiation of the Russian Minority.” Journal of Baltic Studies 40 (1): 95-119.

Weber, Eugen, 1976. Peasants into Frenchmen: The Modernization of Rural France, 1870-1914. Palo Alto, CA: Stanford University Press.

Wilk, Richard R. 1999. "Real Belizean Food: Building Local Identity in the Transnational Caribbean." American Anthropologist 101 (2): 244-255. 
Woolfson, C., 2010. “'Hard Times' in Lithuania: Crisis and 'Discourses of Discontent' in Post-Communist Society." Ethnography 11 (4): 487-514.

Wulf, Meike. 2016. Shadowlands: Memory and History in Post-Soviet Estonia. Oxford: Berghahn Books.

Zanca, Russel. 2003. "Take! Take! Take! Host-Guest Relations and All that Food: Uzbek Hospitality Past and Present." Anthropology of East Europe Review 21 (1): 8-16.

Cite this article: Polese, A. Seliverstova, O. Kerikmae, T. and Cheskin, A. 2020. National Identity for Breakfast: Food Consumption and the Everyday Construction of National Narratives in Estonia. Nationalities Papers 48: 1015-1035, doi:10.1017/nps.2019.131 